\title{
Evaluation of residues of pesticides on humans from medium plant of Rio Grande do Sul, Brazil
}

\author{
Vitória A. Rosano, ${ }^{1}$ Gabriela E. Dal Pizzol, ${ }^{2}$ Maria T. Friedrich, ${ }^{3}$ Charise D. Bertol,,${ }^{1,4}$ \\ Luciana G. Rossato-Grando ${ }^{1,2 *}$
}

\begin{abstract}
Introduction: Pesticide use in Brazil is widespread. General population is concerned about the risks of consuming food containing pesticide residues. Objective: The greatest contribution of this work is to highlight the absence of blood residual contamination in the population of medium plant of Rio Grande do Sul, Brazil, by the pesticides: atrazine, abamectin, chlorpyriphos and diuron. Materials and methods: Pesticide residues were extracted using QuEChERS approach and were quantified by liquid chromatography-mass spectrometry. Results: Most volunteers (92.75\%) present normal levels of plasma cholinesterase and all volunteers do not present residues of any pesticide tested.Conclusion: This study demonstrates that even though the use of pesticides is widespread in our region, the population did not present blood residues or enzymatic changes suggestive of acute intoxication..
\end{abstract}

Keywords: Pesticides; Toxicity; Atrazine; Abamectin; Chlorpyriphos; Diuron.

\section{Resumo}

Avaliação de resíduos de pesticidas em humanos do planalto médio do Rio Grande do Sul, Brasil

Introdução: O uso de agrotóxicos no Brasil é bastante difundido. A população em geral está preocupada com os riscos do consumo de alimentos com resíduos de agrotóxicos. Objetivo: A maior contribuição deste trabalho é destacar a ausência de contaminação residual sanguínea na população do plantalto médio do Rio Grande do Sul, Brasil, pelos pesticidas atrazina, abamectina, clorpirifós e diuron. Materiais e métodos: Os resíduos de pesticidas foram extraídos usando a abordagem QuEChERS e quantificados por cromatografia líquida-espectrometria de massa. Resultados: A maioria dos voluntários (92,75\%) apresenta níveis normais de colinesterase plasmática e todos os voluntários não apresentam resíduos de nenhum pesticida testado. Conclusão: Esse estudo demonstra que mesmo o uso de pesticidas sendo amplo na nossa região, a população não apresentou resíduos no sangue ou alterações enzimáticas sugestivas de intoxicação aguda.

Descritores: Pesticidas; Toxicidade; Atrazina; Abamectina; Clorpirifós; Diuron.
1. Institute of Biological Sciences, University of Passo Fundo. Passo Fundo, RS, Brazil.

2. Graduate Program in Bioexperimentation. University of Passo Fundo, Passo Fundo, RS, Brazil.

3. Graduate Program in Food Science and Technology. University of Passo Fundo, Passo Fundo, RS, Brazil.

4. Human Aging Graduate Program. University of Passo Fundo, Passo Fundo, RS, Brazil.

*Correspondence address:

Av. Brasil Leste, 285

Passo Fundo, RS, Brasil.

CEP: 99052-900.

E-mail: rossatoluciana@upf.br

ORCID: https://orcid.org/0000-0003-4574-855X

BJHBS, Rio de Janeiro, 2020;19(2):108-113

Recebido em 18/08/2020. Aprovado em 27/10/2020.

\section{Resumen}

Evaluación de residuos de plaguicidas en humanos de planta mediana de Rio Grande do Sul, Brasil

Introducción: El uso de pesticidas en Brasil está muy extendido. La población en general está preocupada por los riesgos de consumir alimentos con residuos de plaguicidas. Objetivo: La principal contribución de este trabajo es resaltar la ausencia de contaminación sanguínea residual en la población de plantas medianas de Rio Grande do Sul, Brasil, por los pesticidas atrazina, abamectina, clorpirifos y diurón. Materiales y métodos: Los residuos de plaguicidas se extrajeron mediante el método QuEChERS y se cuantificaron mediante cromatografía líquida-espectrometría de masas. Resultados: La mayoría de los voluntarios $(92,75 \%)$ tienen niveles normales de colinesterasa plasmática y todos los voluntarios no tienen residuos de ningún pesticida probado. Conclusión: Este estudio demuestra que a pesar de que el uso de plaguicidas está muy extendido en nuestra región, la población no presenta residuos sanguíneos ni cambios enzimáticos sugestivos de intoxicación aguda.

Palabras clave: Pesticidas; Toxidad; Atrazina; Abamectina; Clorpirifós; Diuron. 


\section{Introduction}

Pesticides are extensively used to pest and ectoparasites control in agriculture and livestock. At domestic environment, they are employed as desiccants and repellents. ${ }^{1}$ Between 2007 and 2014, pesticide sales increased $149,14 \%{ }^{2}$

The South of Brazil is a region where great part of the economy revolves around agribusiness. Currently, general population is concerned about food contamination by agrochemical residues and its consequences for human health. Thus, consumers are looking for organic diets to reduce this possible contamination. ${ }^{3}$

Human widespread exposure to pesticides is evidenced by the presence of organophosphate and pyrethroid metabolites and phenoxyacid herbicides in urine from people from Asia, Europe, North and Central America, ${ }^{4,5}$ evidencing that human blood contamination are not restricted to agro-professionals. ${ }^{6}$

Population studies carried out in Brazil are also worrying. Between 2012 and 2013 organochlorine residues were described in blood from human population resident in Farroupilha, Rio Grande do Sul. Results suggest that chronic exposure to organochlori-nes are associated with immunosuppression. ${ }^{7}$ Although this is a study also performed in Rio Grande do Sul, it only evaluated the presence of organochlorines, which have been gradually replaced to safer and non-persistent alternatives.

This study aims to evaluate the presence of abamectin, atrazine, chlorpyriphos, and diuron residues in human blood in the population from medium plant of Rio Grande do Sul, South of Brazil. We also evaluated plasmatic cholinesterase levels as a biomarker of organophosphate/carbamate intoxication.

\section{Materials and Methods}

\section{Sample}

The number of volunteers were defined through Simple Random Sample calculation. The equation considered the population from Passo Fundo, Rio Grande do Sul (200 thousand inhabitants). The confidence interval used was $99 \%$ with margin of error of $0.1 \%$.

Two hundred volunteers are considered a number representative of this population. We recruited 207 volunteers, aging between 18 to 65 years old. Participants signed a free and informed consent. Blood (5 $\mathrm{mL}$ ) was collected in EDTA tube, in 8 hours fasting condition and volunteers answered a short questionnaire containing basic personal information. Samples were collected between August and November 2018. This work was approved by the Ethics Commitee on Human Research (Protocol 2.802.812).

\section{Plasma cholinesterase evaluation}

Plasmatic cholinesterase (BuChE) was quantified using comercial kit (BioTécnica ${ }^{\circledR}$, Brazil).

\section{Pesticide residues}

Pesticides evaluated in this work were selected due to their toxicological profile and widespread use in the studied region. General information about pesticides is summarized in Table 1.

Table 1. General information of agrochemicals evaluated in this work

\begin{tabular}{llll}
\hline Agrochemical & Class & Group & Toxicological class \\
\hline Abamectin & Inseticide & Avermectin & Extremely toxic \\
Atrazine & Herbicide & Triazine & Moderately toxic \\
Chlorpiryphos - ethyl & Inseticide & Organophophate & Highly toxic \\
Diuron & Herbicide & Urea & Moderately toxic \\
\hline
\end{tabular}




\section{Original article}

Extraction of pesticide residues from human blood

The extraction of pesticide residues from human blood was performed using QuEChERS (Quick, Easy, Cheap, Effective, Rugged, Safe) approach. ${ }^{8}$ The protocol used here was previously developed and validated to blood samples.

Extraction was performed adding $2 \mathrm{~mL}$ of extraction solution containing methanol: acetonitrile (30:70 + acidophormic acid 0.4\%) to $1 \mathrm{~mL}$ total blood. After $1 \mathrm{~min}$ homogenization, $500 \mathrm{mg}$ of a mixture containing $6 \mathrm{~g}$ magnesium sulphate and $1.5 \mathrm{~g}$ sodium acetate was added. Samples were centrifuged $(5 \mathrm{~min}$, $500 \mathrm{~g}$ ) and $50 \mathrm{mg}$ of a mixture containing $50 \mathrm{mg}$ PSA and $150 \mathrm{mg}$ magnesium sulphate was added to the supernatant. After $30 \mathrm{~min}$ homogenization, the supernatant was removed, filtered and freezed at -80 ${ }^{\circ} \mathrm{C}$ until liquid chromatography coupled with mass spectrometry (LC/MS-MS) analysis.

\section{LC/MS-MS analysis}

A triple quadrupole Shimadzu LC/MS-MS 8040 equipped with a XR-ODS (150 x $2 \mu \mathrm{mm}, 2.2 \mu \mathrm{m})$ column and binary pump was used. The mobile phase consisted in water: methanol containing ammonium acetate $\left(5 \mathrm{mmol} \mathrm{L}^{-1}\right) .^{9}$ Analysis was performed using a flow rate of $0.3 \mathrm{~mL} / \mathrm{min}$ and $10 \mu \mathrm{L}$ of injection volume. Mass detector was triple quadrupole equipped with electrospray ionization (ESI) in the positive mode operating in MS-MS scanning mode. Total run time is 15 min. ${ }^{8}$ In Table 2 , the chromatographic conditions are described.

Table 2. Chromatographic conditions such as retention time, precursor and product ions, collision, and cone energies from pesticides analyzed by LC/MS-MS

\begin{tabular}{|c|c|c|c|c|c|c|c|c|}
\hline \multirow[t]{2}{*}{ Pesticides } & \multirow{2}{*}{$\begin{array}{c}\text { Retention } \\
\text { Time } \\
\text { (min) } \\
\end{array}$} & \multicolumn{3}{|c|}{ Quantifications transition } & \multicolumn{2}{|c|}{ Confirmations transition } & \multicolumn{2}{|c|}{$\begin{array}{l}\text { Limits of detection/ } \\
\text { quantification (ppb) }\end{array}$} \\
\hline & & $\begin{array}{l}\text { Precurson } \\
\text { ion }\end{array}$ & $\begin{array}{l}\text { Production } \\
\text { ion }\end{array}$ & Energy & $\begin{array}{l}\text { Precurson } \\
\text { ion }\end{array}$ & $\begin{array}{l}\text { Production } \\
\quad \text { ion }\end{array}$ & Energy & \\
\hline Abamectin & 12.01 & 890.7 & 305.2 & 28 & 890.7 & 567.40 & 15 & $143.01 / 433.36$ \\
\hline Atrazine & 7.39 & 216.1 & 174.1 & 17 & 216.1 & 96.10 & 25 & $114.10 / 345.77$ \\
\hline Chlorpiryphos-ethyl & 11.11 & 349.8 & 97.0 & 34 & 349.8 & 198.00 & 48 & $56.09 / 169.97$ \\
\hline Diuron & 7.62 & 233.0 & 72.0 & 21 & 233.0 & 160.10 & 26 & $127.18 / 385.39$ \\
\hline
\end{tabular}




\section{Results \& Discussion}

The major finding of this work is to evidence the absence of blood contamination and cholinesterase changes induced by pesticides in general people from medium plant, Rio Grande do Sul, Brazil. To the best our knowledge, this is the first report of blood contamination in this population. The characteristics of studied population are summarized on Table 3.

Organophosphates and carbamates inhibit acetylcholinesterase. This inhibition causes acetylcholine accumulation and, consequently, nicotinic (muscle stiffness, paresis, paralysis) and muscarinic (bradycardia, sudoresis, high intestinal motility) effects. Severe poisoning is associated with central symptoms such as seizures..$^{10}$ The majority of volunteers $(92.75 \%)$ presented normal levels of cholinesterase (Figure 1). This result was expected since this is a populational study and enzyme inhibition occurs only in acute exposure compatible with occupational exposure. However, ten individuals (nine women and one man) presented cholinesterase inhibition, but none of them reported having daily contact with pesticides beyond the possible food contamination. This decrease can be related to verminosis, hepatic disorders ${ }^{11}$ and when estrogen is high during fertile period. ${ }^{12}$ Other five volunteers presented elevated cholinesterase levels. This change might be related to pathologies such as diabetes and hypertension. ${ }^{11}$

We did not detect any of the researched pesticides in blood. This is an important finding, since it enhances the safety to consumers. In Brazil, despite popular concerns, the Program for Analysis of Pesticide Residues in Food (PARA, from ANVISA), revealed that between 2013 and 2015, 80.3\% of analyzed food was considered satisfactory for pesticide waste. It was not

Table 3. Studied population $(n=207)$

\begin{tabular}{|c|c|c|}
\hline & $\mathbf{N}$ & $\%$ \\
\hline \multicolumn{3}{|l|}{ Age, years* } \\
\hline Mean(SD) & $33.47( \pm 13.14)$ & \\
\hline \multicolumn{3}{|l|}{ Sex } \\
\hline Male & 66 & 31.88 \\
\hline Female & 141 & 68.12 \\
\hline \multicolumn{3}{|l|}{ Profession } \\
\hline Rural workers & 14 & 6.76 \\
\hline Students & 78 & 37.68 \\
\hline Non rural workers & 16 & 7.73 \\
\hline \multicolumn{3}{|c|}{ Organic food consumers } \\
\hline Yes & 104 & 50.24 \\
\hline Sometimes & 35 & 16.91 \\
\hline Few times & 4 & 1.93 \\
\hline No & 50 & 24.15 \\
\hline lindifferent & 14 & 6.76 \\
\hline
\end{tabular}

*Mean 


\section{Original article}
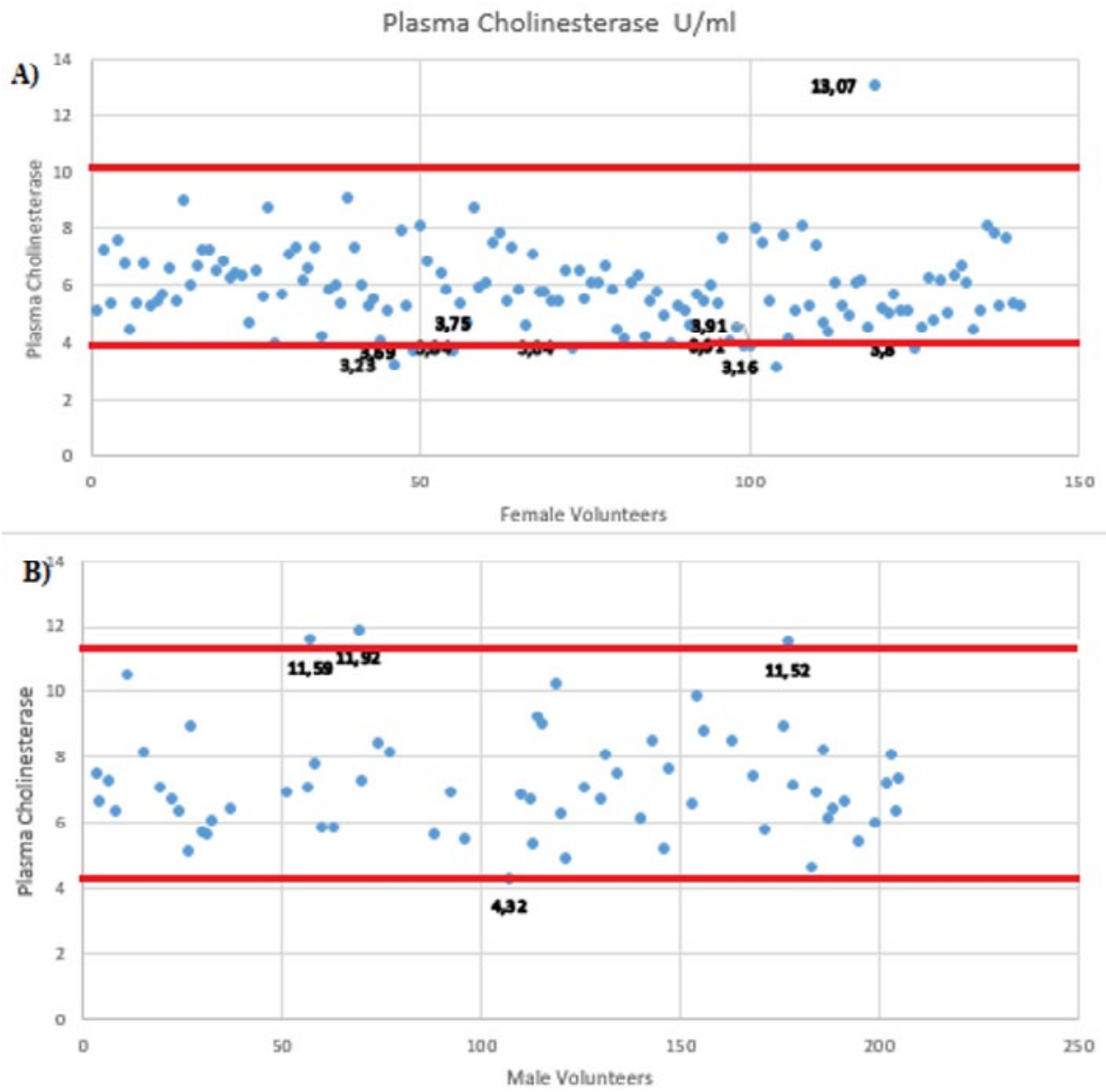

Figure 1. Plasmatic levels of cholinesterase in volunteers. The red lines delimitate reference values $(3,93-10,80 \mathrm{U} / \mathrm{mL}$ female volunteers and $4,62-11,50 \mathrm{U} / \mathrm{mL}$ male volunteers)

detected pesticide waste in $42 \%$ of food sampled and $38.3 \%$ presented pesticide waste less than or equal to maximum allowed limit which is considered safe. ${ }^{13}$ However, chlorpiryphos was present in 342 occurrences in non-approved crops and 1 occurrence with waste higher than maximum allowed limit, ${ }^{13}$ evidencing irregularities in the use of chloriryphos in this country.

From 383 pesticides tested in 27 blood samples of Pakistani rural workers, only chlorpyrifos $(0.009$ $\mathrm{mg} / \mathrm{L}$ ) was found in 1 volunteer. This result suggests the possible degradation of the other residues during this period. It is important to consider that, in general, organophosphates are rapidly metabolized in the environment. ${ }^{14}$ In vivo, their metabolism is relatively fast, and the majority suffers hepatic biotransformation before inhibit acetylcholinesterase. Symptoms of intoxication reach the peak 5 to 8 hours after contact depending on absorption pathway and exposure dose. ${ }^{15}$ Little is known about abamectin degradation route. It is known that abamectin is rapidly absorbed and it is classified as non-persistent in soil and water, despite its leaching power. ${ }^{16,17}$ Diuron is considered one of the most dangerous herbicides to the environment with half-life up to 30 days due to low solubility in water and high chemical stability. ${ }^{18}$ Atrazine' half-life in soil is 50 days and from 105 to 200 days in water, being one of the pesticide most detected in water. ${ }^{19}$ Despite pharmacokinetic particularities, human blood contamination by pesticides was already reported. ${ }^{6}$

Recently, our research group analyzed pesticide residues in organs from owls found dead to evaluate possible bioaccumulation. Although owls did not 
present any blood residue, we found traces of chlorpiryphos-ethyl in liver from 2 samples (unpublished results). Thus, the absence of blood contamination does not exclude the possibility that pesticide residues are accumulating in another human organs.

Studies describing the possible contamination of humans with pesticide are important considering health effects in man from exposure to pesticides. This is also a subject of concern to the population considering the strong association of pesticide exposure to several types of cancer and neurotoxicity. ${ }^{2}$

Even the pesticides studied are widely employed in our region, for the first time it is shown that the resident population does not present residues in blood or enzymatic changes suggestive of acute intoxication related to this exposure. This is an important finding which can increase the sense of security related to agrarian practice.

\section{References}

1. Costa ET. Boletim epidemiológico. 48th ed., 2009; p.1-13.

2. Almeida MD, Cavendish TA, Bueno PC, et al. A flexibilização da legislação brasileira de agrotóxicos e os riscos à saúde humana: análise do projeto de lei $n^{\circ} 3.200 / 2015$. Cad Saúde Pública. 2017;33(7):01-11

3. Hyland C, Bradman A, Gerona R, et al. Organic diet intervention significantly reduces urinary pesticide levels in U.S. children and adults. Environ Res. 2019;171(1):568-75.

4. Li AJ, Martinez-Moral M, Kannan K. Temporal variability in urinary pesticide concentrations in repeated-spot and first-morning-void samples and its association with oxidative stress in healthy individuals. Environ Intern. 2019;130:104904.

5. Sierra-Diaz E, Larosa AC, Lozano-kasten F, et al. Urinary Pesticide Levels in Children and Adolescents Residing in Two Agricultural Communities in Mexico. Int J Environ Res Public Health. 2019;16(4):562.

6. Latif Y, Sherazi STH, Bangher MI, et al. Evaluation of Pesticide Residues in Human Blood Samples of Agro Professionals and Non-Agro Professionals. AJAC. 2012;8(3).

7. Piccoli C, Cremonese C, Koifman R, et al. Occupational exposure to pesticides and hematological alterations: A survey of farm residents in the South of Brazil. Cien Saúde Colet [Internet]. 2017 Sep [Cited 2019]. Available from: http://www.cienciaesaudecoletiva.com.br/artigos/occupational-exposure-to-pesticides-and-hematological-alterations-a-survey-of-farm-residents-in-the-south-of-brazil/16406? id=16406\&id=16406.

8. Friedrich MT, Martins M, Prestes O, et al. Use of Factorial Design in the Development of Multiresidue Method for Determination of Pesticide Residues in Wheat by Liquid Chromatography-Tandem Mass Spectrometry. Food Anal Methods. 2016;9(9):2541-51.

9. Romero-González R, Frenish AG, Vidal JI, et al. Simultaneous determination of pesticides, biopesticides and mycotoxins in organic products applying a quick, easy, cheap, effective, rugged and safe extraction procedure and ultra-high performance liquid chromatography-tandem mass spectrometry. J Chromat A. 2011; 1218(11):1477-85.

10. Chielle EO, Bergmann WCK, Pereira DL. Avaliação da Expressão Sérica da Enzima Colinesterase e de Marcadores Bioquímicos Hepáticos e Renais em Plantadores de Tabaco. 